\title{
Continuous Nitrate Monitoring in Groundwater and Potential Contribution to Surface-Water Nitrogen Loads in Mason County, Illinois
}

\section{Background}

Illinois has some of the most productive farmland in the country. The use of fertilizers to improve crop production has increased, which has resulted in an increase in the concentration of nitrogen in many streams and aquifers (Dubrovsky and others, 2010). The U.S. Geological Survey (USGS), in cooperation with the Illinois Environmental Protection Agency, is continuously monitoring (one reading every 15 minutes) the concentration of nitrate plus nitrite, as nitrogen (hereafter referred to as "nitrate") in a groundwater well and assessing the potential contribution to surface-water nitrogen loads. Continuous monitoring of the nitrate concentration allows for the collection of a larger dataset in comparison to periodic or event-based sampling. This fact sheet describes the data collection methods, describes the overall experimental design, and displays data collected for the study. The analysis of continuous data improves understanding of the fate and transport of nitrate.

From 2000 to 2014, the Illinois Department of Agriculture sampled their network of monitoring wells biennially for concentrations of nitrate. Through this sampling effort, the Illinois Department of Agriculture has identified areas in the State where the nitrate concentration is consistently above the Groundwater Quality Standard of 10 milligrams per liter (mg/L; fig. 1) (K. Rogers, Illinois Department of Agriculture, written commun., 2019). The area in and around Mason County, Illinois, has several wells that have had numerous detections above the Groundwater Quality Standard. These wells are clustered in a shallow glacial aquifer system in a location known as the Havana Lowlands. The sediments of this area primarily consist of hydraulically conductive sands and gravels that rapidly transmit water (Sanderson and Buck, 1995). The Havana Lowlands area is one of the most heavily irrigated agricultural areas in Illinois (Bridges and others, 2014) and is characterized by practices that include extensive center pivot irrigation and the application of water-soluble fertilizer, also known as fertigation. In the 2012 growing season, a total of 1,553 fields were identified as using center pivot irrigation systems in Mason County, Ill. This number represents about 135,000 acres, which is roughly 50 percent of all farmland in the county (Bridges and others, 2014).

In November 2014, the Illinois Environmental Protection Agency and the Illinois Department of Agriculture announced the Illinois Nutrient Loss Reduction Strategy, which is an effort to reduce nutrient loads in surface water within the State of Illinois. A study by the USGS concluded that some of the highest concentrations of nitrates in the Mississippi River were measured during low flow conditions, indicating that a large nutrient load may be transported to the river through groundwater (Murphy and others, 2013). A detailed assessment of nitrate concentrations in groundwater is crucial to understanding how groundwater flow affects nitrate levels in surface water. This study was developed to better understand how nitrate concentration changes in groundwater might affect surfacewater nitrogen loads, which requires quantifying how nitrate concentrations in groundwater change temporally and spatially. These results will provide data for the Illinois Nutrient Loss Reduction Strategy and other nutrient reduction initiatives on the fluctuations of nitrate concentrations in groundwater and its potential loading to surface water in an area of high groundwater discharge.

\section{Continuous Monitoring of Well (U.S. Geological Survey Station 401913089534501)}

On March 8, 2017, a Hach ${ }^{\circledR}$ Nitratax nitrate sensor was installed in a monitoring well (USGS station 401913089534501) that was open to the shallow part of a sand and gravel aquifer. The sensor has a 2-millimeter path length and continuously monitors nitrate concentrations. Additionally, specific conductance, temperature, dissolved oxygen, $\mathrm{pH}$, and water levels are continuously monitored with an In-Situ Aqua TROLL $® 600$ multiparameter sonde to assist with the interpretation of nitrate results.
Before choosing a location for the monitoring well, four reconnaissance borings were made. Groundwater nitrate concentrations were measured at each boring location and the monitoring well was installed at the location where the highest nitrate concentration value was measured. A 4-inch diameter well was required to accommodate the instrumentation. The well was drilled to a depth of 32 feet (ft), a screen installed from 22 to $32 \mathrm{ft}$, and continuous water-quality sensors were suspended from a stainless-steel cable within the screened interval of the casing, which is continually submerged several feet below the water table.

To verify the accuracy of the nitrate concentrations measured by the Nitratax sensor, four discrete samples were collected for laboratory analysis after pumping the well. The water samples were analyzed for nitrate concentrations by the USGS National Water Quality Laboratory in Denver, Colorado (Patton and Kryskalla, 2011). For three of the four discrete samples, the nitrate concentrations measured from the continuous sensor before pumping were verified by the laboratory results and were within the accuracy of the sensor ( 3 percent). The discrete sample not within sensor accuracy was possibly affected by precipitation that occurred during the pumping and sampling of the well. There was some variability in nitrate concentrations during pumping; the variability slightly exceeded the accuracy of the sensor one of the four times that the well was pumped. The remaining times, variability was within sensor accuracy.

As with monitoring in surface water, monitoring in groundwater also has unique challenges and advantages. Data quality from continuous monitors deployed in the environment face potential degradation because of factors such as biological and physical fouling (the formation of unwanted material on a surface to the detriment of function) and calibration drift. These effects are often amplified in surface waters compared to groundwater because of increased biological activity and temperature variability. The continuous monitoring well is visited every $6-8$ weeks, or as needed, to 


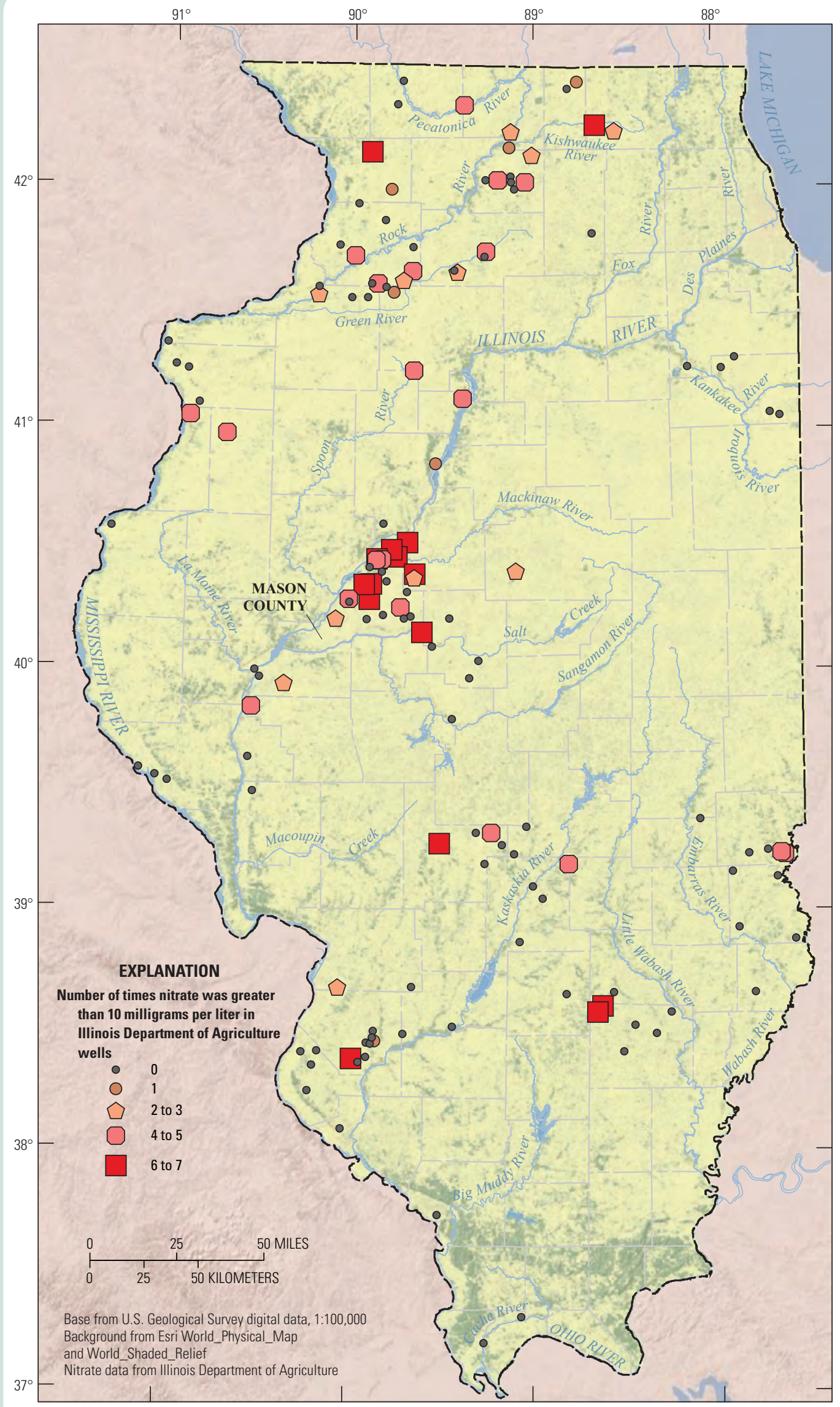

Figure 1. Number of times the nitrate concentration was greater than the Groundwater Quality Standard of 10 milligrams per liter in Illinois Department of Agriculture monitoring wells, sampled seven times, 2000-14 (K. Rogers, Illinois Department of Agriculture, written commun., 2019). monitor potential data-quality degradation. During each visit, sensors are checked for fouling and calibration drift.

The primary advantages of deploying the sensor in a well are the low fouling potential and thermally stable environment. Data collected from March 8, 2017, to August 1, 2018 , indicate fouling is not a concern. And, without the risk of freezing during winter months, year-round deployments are a much easier task in groundwater than in surface water and can provide a more continuous data record. Surface-water deployments are difficult and risky during winter periods because ice can damage or destroy the sensor and (or) the mount supporting the sensor. The primary concern with sensor deployment in a well is having enough groundwater flow through the well screen to avoid measuring stagnant water. Additionally, in groundwater the well diameter limits side-by-side comparison measurements before and after servicing the instrument, which is part of the surface water procedure. Once the deployed sensor in a well is removed, it disturbs the monitoring environment. A similar problem occurs during redeployment of the sensor. Although some parameters recover to premaintenance levels quickly, others take considerable time, making before- and after-fouling checks difficult. The sensor cannot be checked as it is with surface-water environments because of the slower equilibration time in the well. In place of traditional fouling checks, checks in groundwater are being done against calibration standards, where the monitor is checked against the standard before and after sensor cleaning.

\section{Ancillary Data}

To assess the continuous monitoring data from the well, additional instantaneous data were collected using continuous sensors in and near Quiver Creek about 0.6 mile northwest from the monitoring well (USGS station 401913089534501). Quiver Creek, also known as the Mason-Tazewell Drainage Ditch (USGS station 05568704), was developed and modified to drain marshy areas in the county (Sanderson and Buck, 1995). Water in the creek is primarily, if not almost entirely, groundwater discharged from the Mahomet Aquifer (Layne Hydro, 2012).

Starting April 11, 2017, instantaneous nitrate field measurements were collected with a Nitratax sensor in Quiver Creek surface water during visits to the continuous monitoring well. In the spring of 2018, this effort was expanded by installing a series of piezometers to better characterize water quality and hydrology in the Quiver Creek surface water and flood plain. One piezometer is located below the streambed of Quiver Creek (PZ-1), and the other piezometer locations 


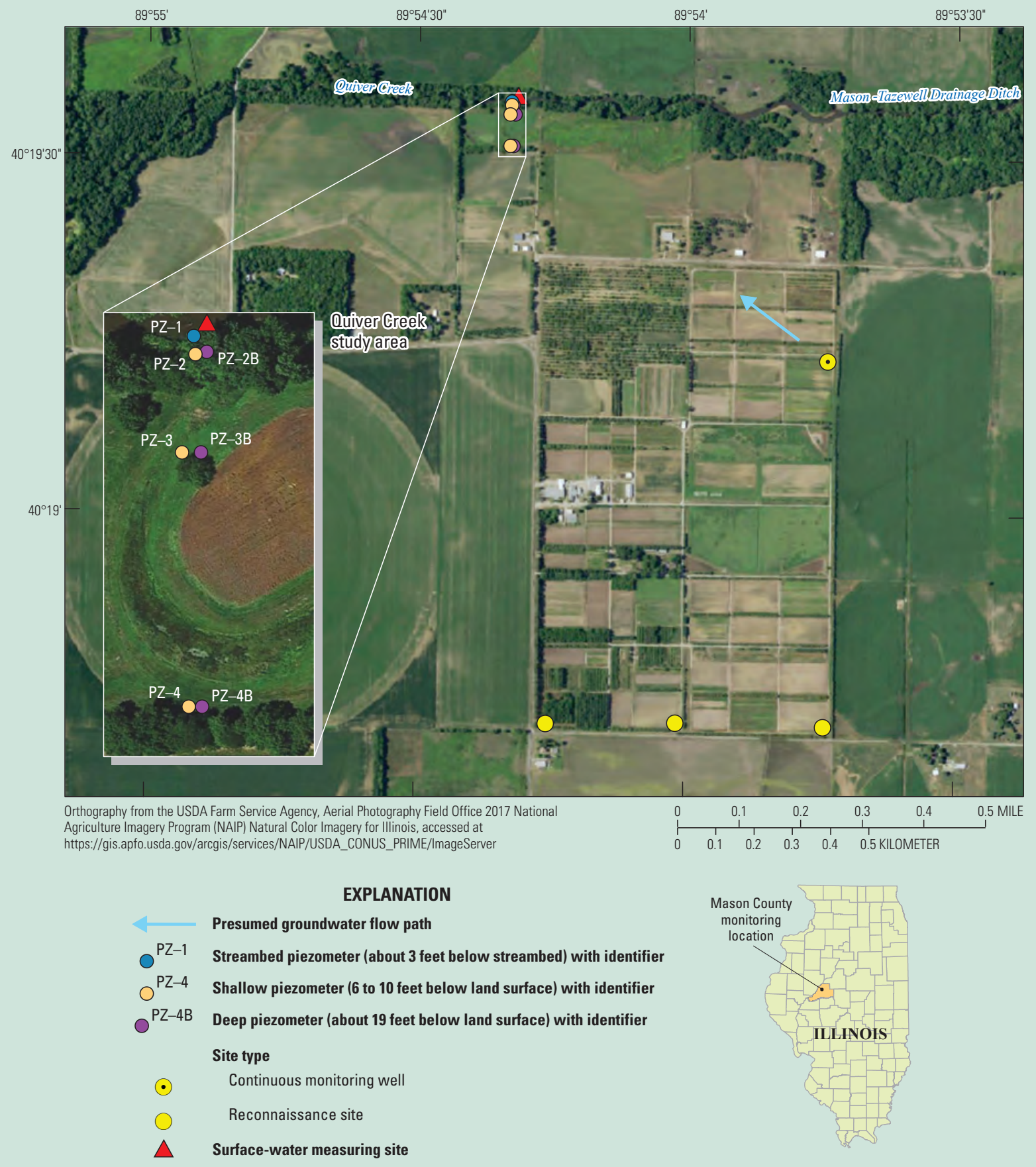

Figure 2. Study area for the project, Mason County, Illinois.

Table 1. Range of nitrate concentrations in piezometers in and near Quiver Creek, Mason County, Illinois, April 4, 2017, to July 18, 2018.

$[<$, less than]

\begin{tabular}{|ccc|}
\hline $\begin{array}{c}\text { Piezometer } \\
\text { identifier }\end{array}$ & $\begin{array}{c}\text { U.S. Geological Survey } \\
\text { station number }\end{array}$ & $\begin{array}{c}\text { Range of nitrate plus nitrite } \\
\text { as nitrogen, } \\
\text { in milligrams per liter }\end{array}$ \\
\hline PZ-1 & 401935089542001 & $<0.10$ \\
\hline PZ-2 & 401934089542001 & $<0.10-8.3$ \\
\hline PZ-2B & 401934089542002 & $<0.10$ \\
\hline PZ-3 & 401933089542001 & $7.60-13.6$ \\
\hline PZ-3B & 401933089542002 & $7.10-9.40$ \\
\hline PZ-4 & 401931089542001 & $16.4-22.7$ \\
\hline PZ-4B & 401931089542002 & $<0.10$ \\
\hline
\end{tabular}



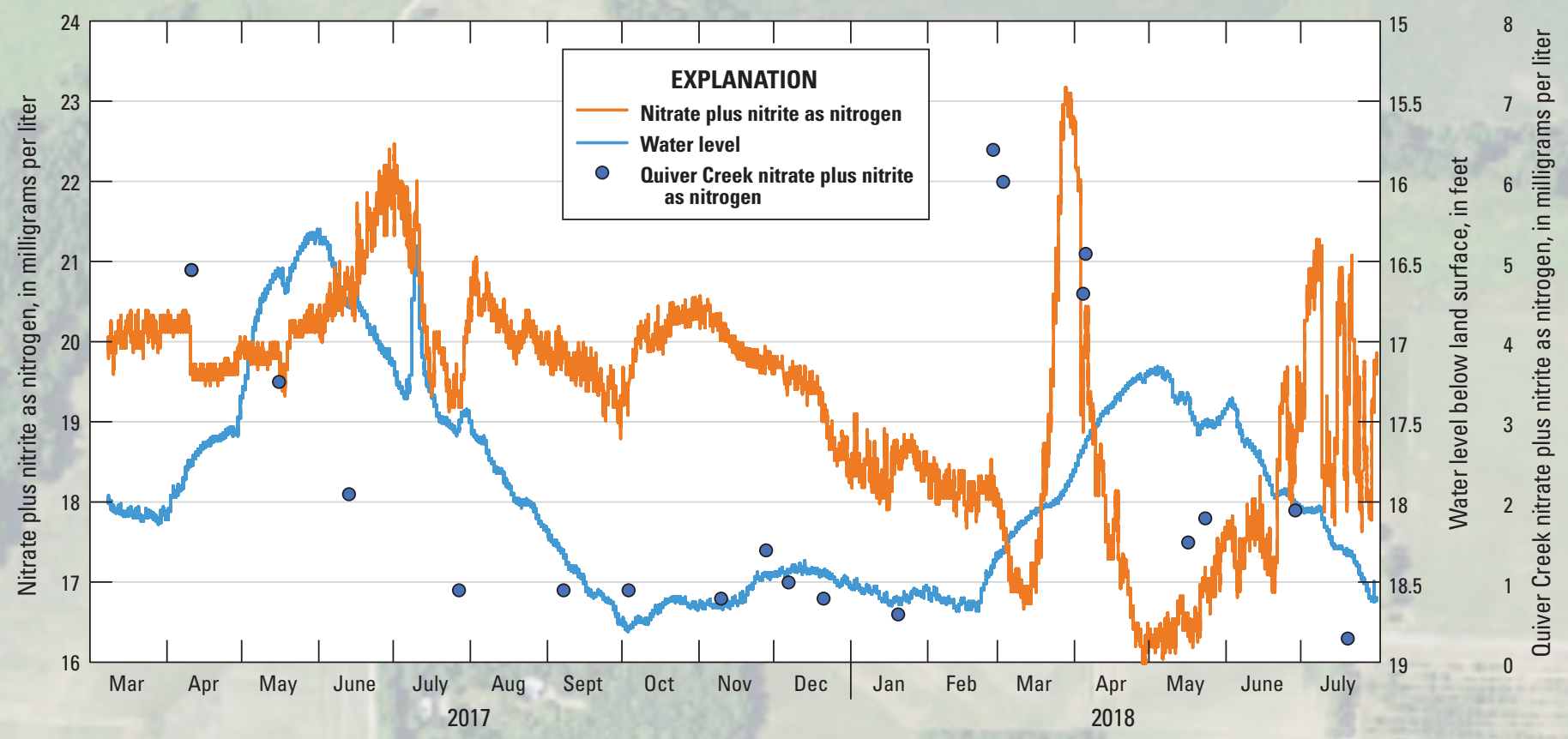

Figure 3. Continuous nitrate concentrations and water levels from the monitoring well (U.S. Geological Survey station 401913089534501) plotted in relation to surface-water nitrate concentrations in Quiver Creek (U.S. Geological Survey station 05568704), Mason County, Illinois, March 8, 2017, to August 1, 2018.

have paired deep and shallow piezometers (fig. 2). One pair is in the bank (PZ-2 and $\mathrm{PZ}-2 \mathrm{~B})$, one pair is about $100 \mathrm{ft}$ landward from the stream (PZ-3 and $\mathrm{PZ}-3 \mathrm{~B})$, and one pair is at the edge of the flood plain near the toe of the upland slope (PZ-4 and PZ-4B). During visits to the monitoring well beginning in spring 2018, instantaneous field measurements of the same water-quality constituents at the well were made in Quiver Creek surface water and in all piezometers. The piezometers were pumped during visits for 12 minutes; then, readings taken every 2 minutes to determine a stable median value for each constituent.

\section{Nitrate Concentrations in Groundwater and Surface Water}

Continuously measured groundwater nitrate concentrations at the monitoring well (USGS station 401913089534501) from March 8, 2017, to August 1, 2018, ranged from 16.0 to $23.1 \mathrm{mg} / \mathrm{L}$, whereas instantaneous field measurements of nitrate concentrations in Quiver Creek during this time ranged from 0.90 to $6.40 \mathrm{mg} / \mathrm{L}$ (fig. 3). All continuous water-level and water-quality data are available on the USGS National Water Information System (U.S. Geological Survey, 2019). Median field measurements of nitrate concentrations from the pumped piezometers show considerable variability laterally and vertically across the Quiver Creek flood plain (table 1). Measuring nitrate in this experimental design will add to the understanding of the fate and transport of nitrate as it moves through groundwater to surface water.

\section{References}

Bridges, K., Wilson, S., and Perry, R., 2014, 2012 center pivot irrigation in Mason County, Illinois: Illinois State Water Survey Map Series 2014-01, 1 p., scale 1:85,000, accessed May 2019 at https://www.isws. illinois.edu/docs/default-source/maps/2012center-pivot-irrigation-mason-countyillinois.pdf? sfvrsn $=5 \mathrm{~b} 30 \mathrm{~d} 2 \mathrm{c} 0 \_2$.

Dubrovsky, N.M., Burow, K.R., Clark, G.M., Gronberg, J.M., Hamilton, P.A., Hitt, K.J., Mueller, D.K., Munn, M.D., Nolan, B.T., Puckett, L.J., Rupert, M.G., Short, T.M., Spahr, N.E., Sprague, L.A., and Wilber, W.G., 2010, The quality of our Nation's waters - Nutrients in the Nation's streams and groundwater 1992-2004: U.S. Geological Survey Circular 1350, 174 p., accessed May 2019 at https://water.usgs.gov/nawqa/ nutrients/pubs/circ1350.

Layne Hydro, 2012, Petition to designate the Mahomet Aquifer as a Sole Source Aquifer: City of Champaign, Town of Normal, City of Urbana, University of IllinoisChampaign/Urbana, Village of Savoy, City of Develan, Village of Mahomet, Village of Mansfield, City of Gilman, 108 p.

Murphy, J.C., Hirsch, R.M., and Sprague, L.A., 2013, Nitrate in the Mississippi River and its tributaries, 1980-2010-An update: U.S. Geological Survey Scientific Investigations Report 2013-5169, 31 p., accessed May 2019 at https://pubs.usgs. gov/sir/2013/5169/.
Patton, C.J., and Kryskalla, J.R., 2011, Colorimetric determination of nitrate plus nitrite in water by enzymatic reduction, automated discrete analyzer methods: U.S. Geological Survey Techniques and Methods, book 5, chap. B8, 34 p., accessed April 2019 at https://doi.org/10.3133/tm5B8.

Sanderson, E.W., and Buck, A.G., 1995, Reconnaissance study of the groundwater levels in the Havana Lowlands area: Champaign, Ill., Illinois State Water Survey Contract Report 582, 36 p., accessed April 2019 at http://citeseerx.ist.psu.edu/viewdoc/download?doi $=10.1 .1 .614 .5199 \& \mathrm{rep}=\mathrm{r}$ ep $1 \&$ type $=$ pdf.

U.S. Geological Survey, 2019, USGS water data for the Nation: U.S. Geological Survey National Water Information System database, accessed May 3, 2019, at https://doi. org/10.5066/F7P55KJN.

—By Lance R. Gruhn and Greg M. Nalley

\section{For more information about this publication, contact:}

Director, Central Midwest Water Science Center U.S. Geological Survey

405 N. Goodwin Ave.

Urbana, Illinois 61801

(217) 328-8747

https://www.usgs.gov/centers/cm-water 